\title{
Mesenchymal stem cells from sternum: the type of heart disease, ischemic or valvular, does not influence the cell culture establishment and growth kinetics
}

\author{
Lucinara Dadda Dias', Karina Rabello Casali², Carine Ghem³, Melissa Kristocheck da Silva', Grasiele Sausen', \\ Patrícia Bonini Palma ${ }^{4}$, Dimas Tadeu Covas ${ }^{4}$, Renato A. K. Kalil ${ }^{1,5}$, Beatriz D. Schaan ${ }^{6}$, Nance Beyer Nardi ${ }^{1,7}$ \\ and Melissa Medeiros Markoski ${ }^{1,5^{*}}$ (1)
}

\begin{abstract}
Background: In an attempt to increase the therapeutic potential for myocardial regeneration, there is a quest for new cell sources and types for cell therapy protocols. The pathophysiology of heart diseases may affect cellular characteristics and therapeutic results.

Methods: To study the proliferative and differentiation potential of mesenchymal stem cells (MSC), isolated from bone marrow (BM) of sternum, we made a comparative analysis between samples of patients with ischemic (IHD) or non-ischemic valvular (VHD) heart diseases. We included patients with IHD $(n=42)$ or VHD $(n=20)$, with average age of 60 years and no differences in cardiovascular risk factors. BM samples were collected $(16.4 \pm 6 \mathrm{~mL}$ ) and submitted to centrifugation with Ficoll-Paque, yielding $4.5 \pm 1.5 \times 10^{7}$ cells $/ \mathrm{mL}$.

Results: Morphology, immunophenotype and differentiation ability had proven that the cultivated sternal BM cells had MSC features. The colony forming unit-fibroblast (CFU-F) frequency was similar between groups $(p=0.510)$, but VHD samples showed positive correlation to plated cells vs. CFU-F number $(r=0.499, p=0.049)$. The MSC culture was established in $29 \%$ of collected samples, achieved passage 9 , without significant difference in expansion kinetics between groups ( $p>0.05$ ). Dyslipidemia and the use of statins was associated with culture establishment for IHD patients ( $p=0.049$ and $p=0.006$, respectively).
\end{abstract}

Conclusions: Together, these results show that the sternum bone can be used as a source for MSC isolation, and that ischemic or valvular diseases do not influence the cellular yield, culture establishment or in vitro growth kinetics.

Keywords: MSC establishment, Stem cells culture, Cell therapy, Valvular heart disease, Ischemic heart disease

\section{Background}

In recent years, great attention has been given to the use of cell-based therapy in cardiology, with a number of clinical trials [1-3] that have been subjected to systematic reviews and meta-analyses [4-6]. Most of

\footnotetext{
*Correspondence: melissa.markoski@gmail.com

1 Programa de Pós-graduação em Ciências da Saúde-Cardiologia, Instituto de Cardiologia/Fundação Universitária de Cardiologia, Avenida Princesa Isabel, $n^{\circ} 370,3^{\circ}$ andar, Porto Alegre, RS CEP: 90620-001, Brazil Full list of author information is available at the end of the article
}

these studies have used bone marrow mononuclear cells (BMMC) obtained by iliac crest bone marrow (BM) aspiration [5]. The BM contains two types of adult stem cells: the hematopoietic stem cells give rise to blood cells [7], and the non-hematopoietic stem cells, or mesenchymal stem cells (MSC), contribute to the regeneration of mesenchymal tissues such as bone, cartilage and muscle [8]. In addition to their ability to differentiate into cellular components of the heart, such as endothelial cells and cardiomyocytes $[9,10]$, MSC are also able to release 
a great number of cytokines and chemokines, which can mediate the processes of tissue regeneration $[8,11]$. For all these reasons, MSC have attracted increasing attention as a source of cells for cardiac regenerative therapy.

Since MSC are present in a low frequency in the BM (0.001-0.01\%) [12], their use in clinical protocols requires ex vivo expansion and maintenance for 4-5 [13] or 6-8 weeks [14], depending on the pathology, so that a sufficient number of cells can be produced [15]. It is known that in aged individuals MSC have reduced frequency, capacity of expansion in culture $[16,17]$ and cellular fitness [18], factors that compromise the expansion of these cells in culture. Another problem relates to the limited capacity of expansion of BM cells after isolation and injection in patients who had had a myocardial infarction with consequent cardiomyocyte loss [19].

Considering that different heart diseases have different pathophysiological mechanisms, it is expected that cellular therapy for each of these diseases would have different results. This is the case of using cell therapy for heart failure determined by myocardial ischemia or by valve diseases, with BMMC or MSC [15, 20, 21]. The assessment of the ex vivo behavior of MSC isolated from elderly heart diseases patients with similar risk factors may provide valuable information for the choice of cell sources. The characterization of bone marrow-derived MSC is extremely important, since these patients represent of the main groups of interest for cell therapy and any loss in number or in cellular functionality can generate profound consequences for tissue regeneration processes.

The present study aims to quantify and analyze MSC isolated from sternal BM of patients with ischemic or non-ischemic valvular heart disease, evaluating the frequency of colony forming unit-fibroblast (CFU-F), the potential of establishing in vitro cultures and the kinetics of cultures until reaching senescence, as well as the differentiation potential. Clinical characteristics of patients, as well as the pharmacology in using, were also analyzed and correlated to the ability of establishment of cell cultures.

\section{Methods}

\section{Patients}

Patients with ischemic heart disease (IHD) or non-ischemic valvular heart diseases (VHD), between 50 and 75 years old, and referred for coronary artery bypass grafting or valve replacement surgery respectively, were included. Exclusion criteria were presence of hematologic diseases, previous heart complications and cancer diagnosis. The study was approved by the Research Ethics Committee of Instituto de Cardiologia (Process Number 4397/09), and was conducted in accordance with the Declaration of Helsinki. Written informed consent was obtained from all patients.

\section{Evaluation of clinical parameters}

The clinical data were obtained from medical records, where we evaluated the age, the gender, the presence of systemic arterial hypertension (defined by blood pressure greater than 140/90 $\mathrm{mmHg}$ and by the use of antihypertensive medication), dyslipidemia (total cholesterol levels greater than $200 \mathrm{mg} / \mathrm{dL}$, triglycerides grater than 150 and HDL-cholesterol grater than 40 for men and 50 for women, in addition to the use of lipid-lowering medication), diabetes mellitus (defined by glycemia exceeding $180 \mathrm{mg} / \mathrm{dL}$ and the use of oral hypoglycaemic or insulin), smoking (patients were considered smokers as declared smoking at the time of entering the study or who declared having stopped smoking until 10 years before entering the study). It was also considered the use of medications such as angiotensin-converting enzyme inhibitor, statins, antiplatelet drugs, diuretics, beta blockers and insulin.

\section{Isolation and cultivation of sternum MSC}

The sternal $\mathrm{BM}$ was aspirated using a $10 \mathrm{~mL}$ syringe and $1.20 \times 40 \mathrm{~mm}$ needles, with $1.5 \mathrm{mg}$ EDTA $/ \mathrm{mL}$ BM. BMMC were isolated by centrifugation over Ficoll-Paque Plus (GE Heathcare Life Sciences, Uppsala, Sweden). Cells from the mononuclear layer were washed, counted with trypan blue and resuspended in complete culture medium, composed of low-glucose Dulbecco's modified Eagle's medium (DMEM, Gibco-Carlsbad, SP, Brazil) with 15\% fetal bovine serum (Cultilab, SP, Brazil), $100 \mathrm{U} /$ $\mathrm{mL}$ penicillin and $100 \mathrm{mg} / \mathrm{mL}$ streptomycin (Cultilab). Cells were plated in duplicate samples in 12-well culture plates, at $2.8 \times 10^{6} \mathrm{BMMC} / \mathrm{cm}^{2}$ and incubated at $37{ }^{\circ} \mathrm{C}$ in a humidified, $5 \% \mathrm{CO}_{2}$ incubator for $72 \mathrm{~h}$, when nonadherent cells were removed by changing the medium. The medium was changed twice weekly. For expansion of cultures the cells were passaged (split) when they reached $80-85 \%$ of area confluence. For this, the medium was removed and adherent cells were washed twice with phosphate-buffered saline (PBS, pH 7.4) and incubated with $0.05 \%$ Trypsin-EDTA (Gibco) for about $5 \mathrm{~min}$ at $37^{\circ} \mathrm{C}$. Cultures were considered successful when reaching the passage 3 (P3). Plastic ware was from BectonDickinson (BD Biosciences, San Jose, CA, USA).

\section{Proliferation kinetics}

MSC were analyzed for proliferation capacity in two stages. In the first one, BMMC were initially plated in duplicate samples in 12-well culture plates, at $2.8 \times 10^{6}$ cells $/ \mathrm{cm}^{2}$ and passaged at $80-85 \%$ confluence. From $\mathrm{P} 1-\mathrm{P} 3$, cells were plated at different densities $(10,18$ and $75 \times 10^{3}$ cells $/ \mathrm{cm}^{2}$, respectively). From passage 4 on, a protocol adapted from Stolzing et al. [18] was used. Briefly, MSC were plated in triplicate samples in 6-well culture plates at $10^{4}$ cells $/ \mathrm{cm}^{2}$ and passaged at $80-85 \%$ 
confluence at the same density. Cells were maintained in culture and counted at every passage, until proliferation stopped.

The population doubling (PD), cumulative population doubling (CPD) and cumulative days were determined as previously described [22]. The population doubling time (PDT) was calculated at P3 and P9 as $t / \mathrm{n}$, where $t$ is the duration of culture in days and $\mathrm{n}$ is the number of PD.

\section{Immunophenotyping}

Cells were used in P3, centrifuged, and incubated for $30 \mathrm{~min}$ at room temperature in the dark with PE-conjugated (anti-CD49e, CD166, CD14, CD146, HLA-ABC, CD105 and CD73), FITC-conjugated (anti-CD31, CD45, CD51/CD61, CD44, CD29, HLA-DR, CD90 and CD106), PerCP-conjugated anti-CD34, APC-conjugated antiCD13 antibodies and respective isotype controls (BD Biosciences). The cells were analyzed using a FACS Calibur cytometer (Becton-Dickinson, San Diego, CA, USA) with the CellQuest Pro software. At least 10,000 events were collected. Forward scatter (FSC) and side scatter (SSC) were used for gating on staining cells and excluding cell debris.

\section{MSC differentiation}

MSC cultures (P3) at 80\% confluence were kept for 21 days in osteogenic- or adipogenic-inducing media [23, 24]. Controls were maintained in standard medium for the same period. Experiments were performed in triplicates. Differentiation was analyzed with Alizarin Red $\mathrm{S}$ or Oil Red $O$ (Sigma-Aldrich, St Louis, MO), respectively, according to Kretlow et al. [24]. In each well, five randomly selected fields were photographed with an AxioCam camera (Carl Zeiss, Hallbergmoos, Germany). Stained areas were quantified using the Image-Pro Plus software and expressed as percentage of the total analyzed area.

\section{Colony forming unit-fibroblast assay}

The CFU-F assay was performed as previously described $[18,25]$. BMMC were resuspended in complete culture medium and plated in duplicate samples in 6-well culture plates, at $5 \times 10^{5}, 10^{6}$ and $10^{7} \mathrm{BMMC} /$ well. Medium was changed on days 3 and 8 of culture. On day 14th, cultures were fixed and stained with May-Grünwald-Giemsa and colonies (groups of $>30$ fibroblastoid cells) were counted. The CFU-F frequency was calculated based on the respective input cell number as CFU-F per $1 \times 10^{6}$ BMMC.

\section{Statistical analyses}

The data were tested for normality using a Kolmogorov-Smirnov test. The results are expressed as mean \pm standard deviation (SD) or median and interquartile intervals. Groups were compared using parametric tests (Student's $t$ test) for CPD, cumulative days, and CFU-F or non-parametric tests (Mann-Whitney test) for analysis of PDT and MSC differentiation. The Chi square test was used to compare the rate of success in establishing MSC cultures, and the Fisher's exact test for comparing characteristics between groups. The level of significance was set at $5 \%$ for all tests. Statistical analyses were performed with the SPSS software package, version 19.0, and Graphpad Prism 5.

\section{Results}

\section{Characterization of the sample}

A total of 62 patients were included in the study (IHD, $\mathrm{n}=42$; VHD, $\mathrm{n}=20$ ). As presented in Table 1 , most characteristics were similar between groups. The use of diuretics was higher in the VHD group, male sex frequency, statins use, use of antiplatelets and beta-blockers was higher in IHD patients, as expected.

\section{MSC from sternum of IDH and VHD patients can be established and cultivated in vitro}

The mean volume of sternal BM collected was $16.4 \pm 6 \mathrm{~mL}$, which yielded in average $4.5 \pm 1.5 \times 10^{7}$ cells $/ \mathrm{mL}$ of tissue. We considered a successful establishment when cultures reached the P3. However, between the 42 IHD samples, 6 reached only P1 and other 3 samples stop proliferation before P2; and, in 20 isolated samples of VHD patients, 2 stopped proliferation before P2, being in culture for up to 40 days. Thus, of the 62 samples analyzed, the successful

Table 1 Clinical characteristics of patients with ischemic (IHD) or non-ischemic valvular heart disease (VHD)

\begin{tabular}{llll}
\hline Variables & IHD (n= 42) & VHD (n= 20) & $\mathbf{p}$ \\
\hline Age (years) & $59.30 \pm 6.61$ & $62.35 \pm 8.82$ & 0.135 \\
Male & $37(88.1)$ & $13(65.0)$ & 0.043 \\
Hypertension & $34(81.0)$ & $14(70.0)$ & 0.349 \\
Diabetes mellitus & $13(31.0)$ & $3(15.0)$ & 0.226 \\
Smoking & $30(71.4)$ & $10(50.0)$ & 0.155 \\
Dyslipidemia & $6(14.3)$ & $3(15.0)$ & 1.000 \\
Medications in use & & & \\
$\quad$ Angiotensin-converting enzyme & $26(61.9)$ & $13(65.0)$ & 1.000 \\
$\quad$ inhibitor & & & 0.049 \\
Statins & $28(66.7)$ & $7(36.8)$ & 0.012 \\
Antiplatelet drugs & $30(71.4)$ & $7(35.0)$ & 0.001 \\
$\quad$ Diuretics & $6(14.3)$ & $12(60.0)$ & 0.545 \\
Insulin & $1(2.4)$ & $1(5.0)$ & 0.002 \\
Beta-blockers & $30(71.4)$ & $6(30.0)$ &
\end{tabular}

Age described as mean \pm standard deviation; other variables as $\mathrm{n}$ and percentage (\%)

$I H D$ ischemic heart disease, VHD non-ischemic valvular heart disease

Statistical analysis by Fisher's exact test $(a=5 \%)$ 
establishment of cultures characterized as MSC was 29\% $(\mathrm{n}=18)$. The percentage of MSC established cultures did not differ $(\mathrm{p}=0.189)$ between the groups IHD and VHD (23.8\%, $\mathrm{n}=10$, and $40 \%, \mathrm{n}=8$, respectively) (Fig. 1a). Considering the influence of the clinical parameters in the MSC establishment, we found that the presence of dyslipidemia, as well as patients who used statins, both in the IHD group, were features that were significantly associated with the presence of in vitro cell cultivation $(\mathrm{p}=0.049$ and $\mathrm{p}=0.006$, respectively). No other parameter (reported in Table 1) showed association with the presence or the absence of culture establishment of MSC. The same was observed when patients of IHD and VHD groups were considered separately or grouped $(\mathrm{p}>0.05)$. Young cultures (P1 to P3) showed a fibroblast-like morphology, with a well-delimited nucleus and with regular borders (Fig. 1b). In older cultures $(\geq \mathrm{P} 3)$, the fibroblastic morphology was modified, and larger cytoplasms and irregular borders as well as intracellular debris were observed (Fig. 1c).

\section{Cultured cells from sternum of IHD and VHD patients have characteristic MSC immunophenotype and ability to in vitro differentiation}

MSC cultures isolated from IHD and VHD patients showed a characteristic surface profile, with low or no expression ( $<2 \%$ of events) of hematopoietic (CD34, CD14, CD45) and endothelial (CD51/61, CD31, CD146) markers and HLA-ABC, as well as of HLA-DR and CD106, and presence of CD73, CD105, CD166, CD90, CD13, CD29, CD49e, CD44 (Fig. 2). The analysis of cell size and granularity (FSC and SSC, respectively) and counts for antibody-isotype controls may be seen in the Additional file 1. Further, in samples from both groups, the osteogenic and adipogenic differentiations were observed in 60 and 75\%, respectively, of MSC cultures treated with inducing media comparing to controls (Fig. 3). Besides, there was no difference between the adipogenic $(p=0.461)$ or osteogenic $(p=0.635)$ differentiation rates for samples isolated from patients with IHD and VHD.

\section{The type of heart disease does not affect proliferative capacity of MSC isolated from sternum Quantification of CFU-F frequency}

Figure 4 shows the average CFU-F count obtained from BMMC samples isolated from sternum of patients with IHD or VHD. The CFU-F frequencies were similar to both cardiopathies, being $1 / 1.1 \times 10^{6}$ and $1 / 1.2 \times 10^{6}$, respectively $(\mathrm{p}=0.510)$. There was a positive correlation $(\mathrm{r}=0.499 ; \mathrm{p}=0.049)$ between the number of plated cells and the number of CFU-F in the VHD group, however, the same did not occur for the IHD group $(r=0.188$; $\mathrm{p}=0.302)$.

\section{Proliferation and expansion kinetics}

From P1 to P3, the expansion rates of individual MSC cultures derived from IHD and VHD samples showed a large variation, with eightfold duplication of the initial population in some of the cultures and only one in others (Fig. $5 \mathrm{a}-\mathrm{c}$ ). From passage 4 on, however, cultures showed
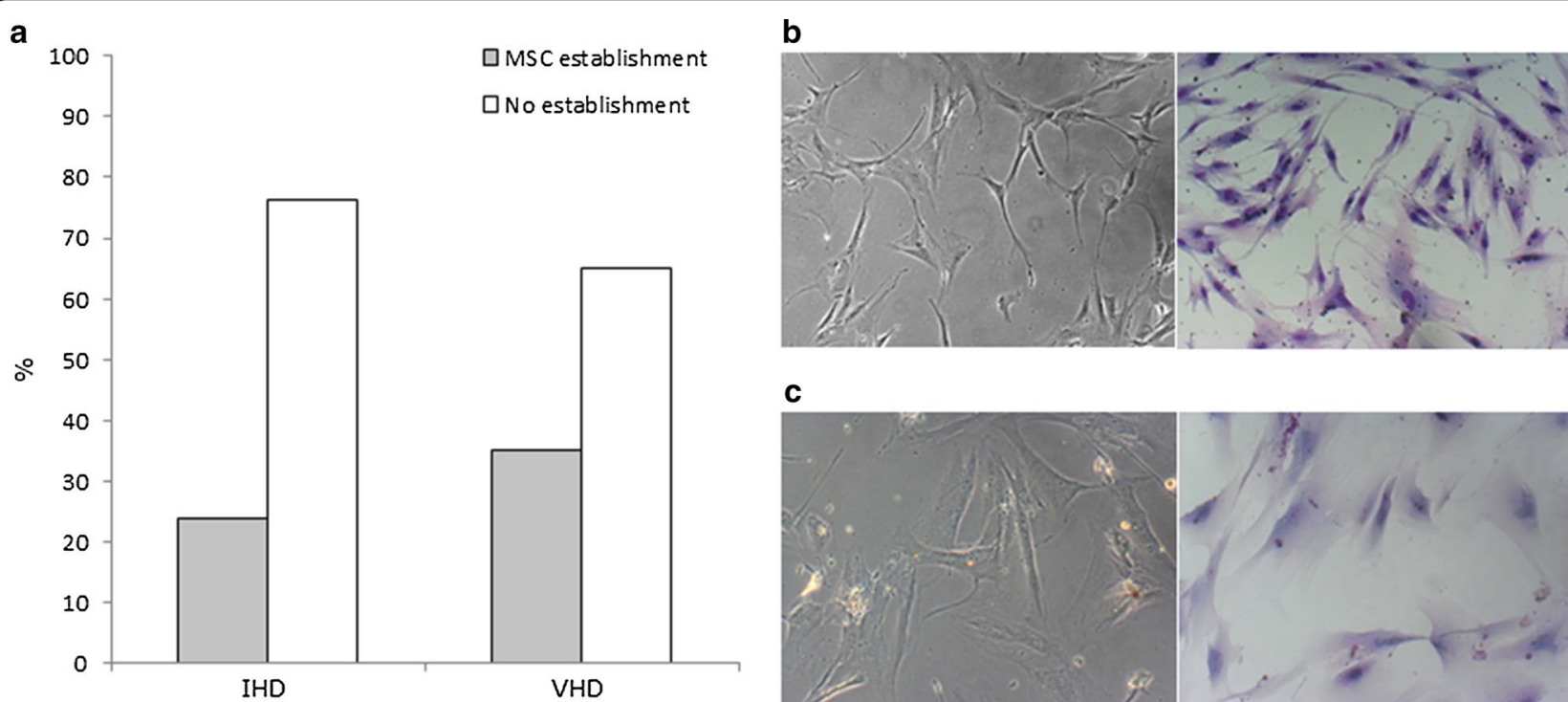

C

Fig. 1 Quantification analysis of sternum MSC establishment and cell morphology. a Percentages of samples with or without establishment of cell cultures (overcoming P3) for ischemic (IHD) and non-ischemic valvular heart disease (VHD) $(p=0.189)$. b Young (P1) and colder (P9) cultures, under phase contrast microscopy (left) and stained with May-Grünwald-Giemsa (right). Original magnifications $\times 100$ 

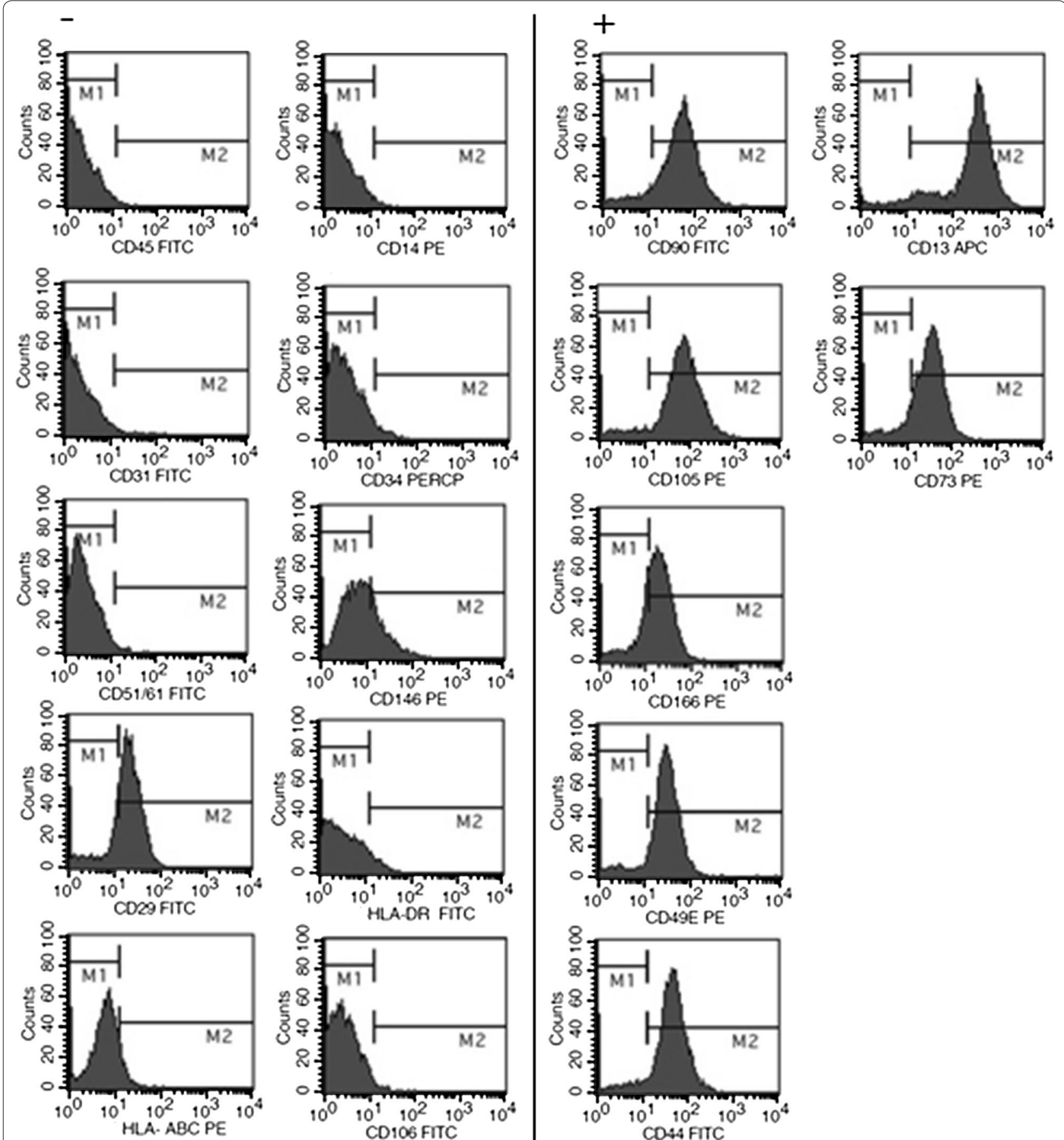

Fig. 2 Representative immunophenotype profile of MSC cultures isolated from sternum of ischemic (IHD) and non-ischemic valvular heart disease (VHD). Positive (right) and negative (left) staining for MSC, hematopoietic and endothelial cell populations analyzed by flow cytometry

a low proliferation capacity or stopped proliferation (Fig. 5b-d). Four of the 10 established cultures from IHD samples, were maintained after P4, and only three were maintained after P7 (Fig. 5a, b). Six of the 8 MSC cultures established from VHD samples were maintained after
P4 and only two after P6 (Fig. 5c, d). No differences were observed between the two groups of cultures regarding the expansion rate (CPD, Fig. $6 \mathrm{a}-\mathrm{C})$ in each passage (P1, $\mathrm{p}=0.905 ; \mathrm{P} 2, \mathrm{p}=0.447 ; \mathrm{P} 3, \mathrm{p}=0.827 ; \mathrm{P} 4, \mathrm{p}=0.839 ; \mathrm{P} 5$, $\mathrm{p}=0.221 ; \mathrm{P} 6, \mathrm{p}=0.514 ; \mathrm{P} 7, \mathrm{p}=0.703 ; \mathrm{P} 8, \mathrm{p}=0.740$; 

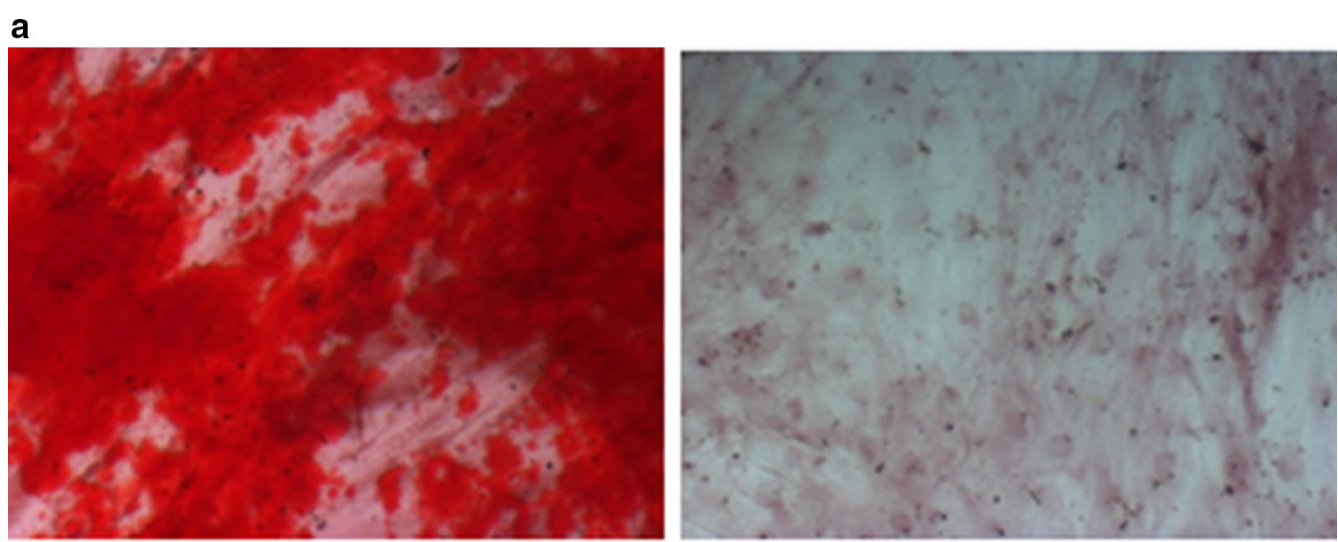

\section{b}
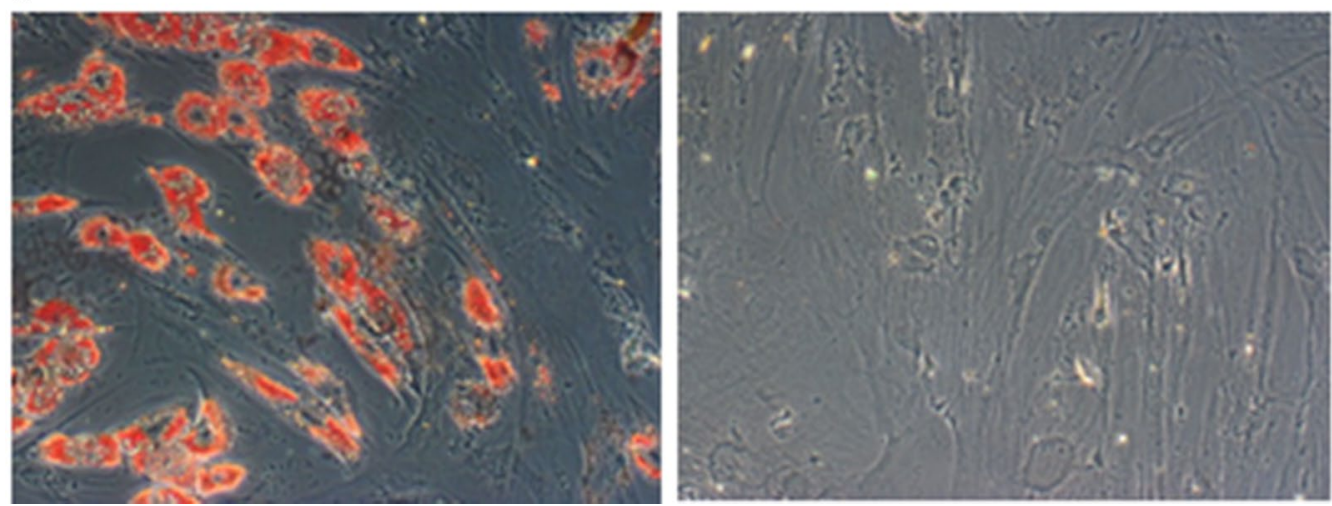

Fig. 3 Differentiation ability of MSC cultures from sternum of ischemic (IHD) and non-ischemic valvular heart disease (VHD) patients. Representative micrography of positive (induced, right) and negative (control, left) staining for a Alizarin Red S (osteogenic marker) and for b Oil Red O (adipogenic marker). Original magnifications $\times 100$

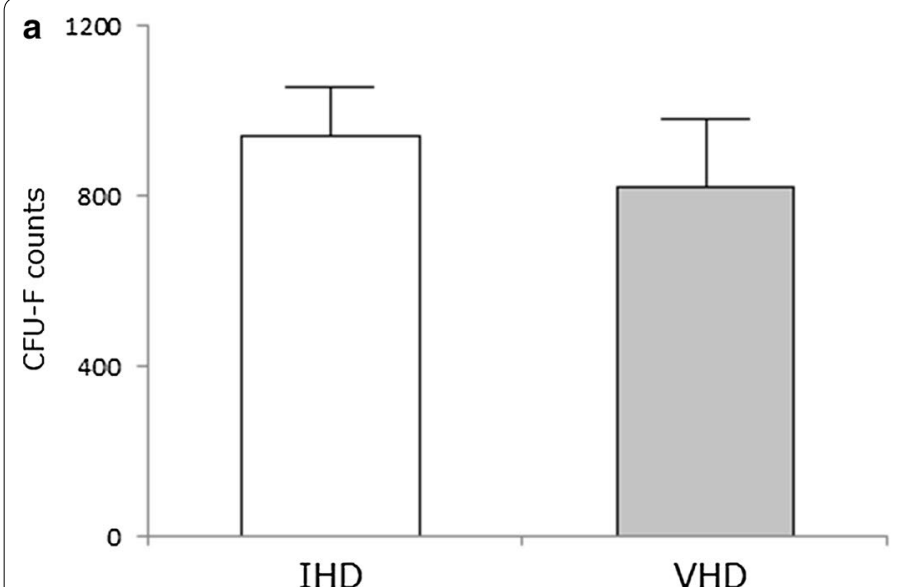

b



Fig. 4 CFU-F counts from sternal BM of ischemic (IHD) and non-ischemic valvular heart disease (VHD) patients. The BMMC separated from sternal $\mathrm{BM}$ were seeded in values varying between $5 \times 10^{5}$ and $1 \times 10^{7}$ cells. a Bars show the average number of colony forming unit-fibroblast (CFU-F) counted after 14 days and related to $1 \times 10^{6} \mathrm{BMMC}$ seeded for each disease. b Representative image of CFU-F from IHD (upper wells) and VHD (bottom wells) samples in different concentrations of seeding 


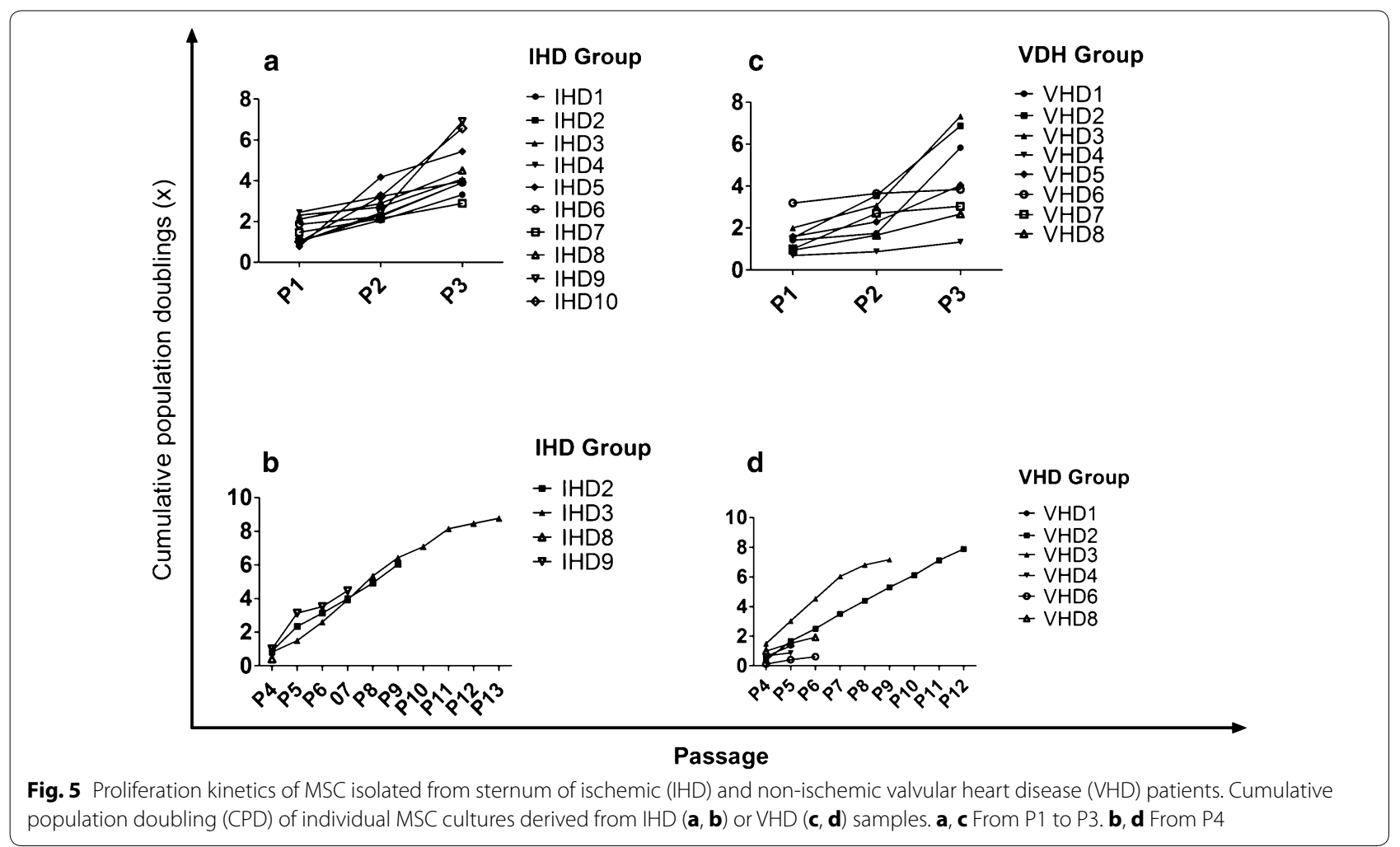

P9, $\mathrm{p}=1.00$ ). No differences were observed between the two groups in the number of days to reach $80-85 \%$ confluence (cumulative days, Fig. 6b-d) in each passage (P1, $\mathrm{p}=0.351 ; \mathrm{P} 2, \mathrm{p}=0.439 ; \mathrm{P} 3, \mathrm{p}=0.283 ; \mathrm{P} 4, \mathrm{p}=0.789 ; \mathrm{P} 5$, $\mathrm{p}=0.757 ; \mathrm{P} 6, \mathrm{p}=0.771 ; \mathrm{P} 7, \mathrm{p}=0.881 ; \mathrm{P} 8, \mathrm{p}=0.583 ; \mathrm{P} 9$, $\mathrm{p}=0.484$ ), or in the PDT measured at P3 (IHD, 7.7 days to 5.5-8.5 days-vs. VHD, 6.5 days to $4.5-8.8$ days; $\mathrm{p}=0.696$ ) or P9 (IHD, 11.1 days to $5.2-15.8$ days-vs. VHD, 7.4 days to $3.7-16.5$ days; $\mathrm{p}=0.730$ ).

\section{Discussion}

The present study described for the first time the frequency and the functionality of MSC isolated from the sternal bone marrow of two groups of patients with distinct heart diseases. We showed that cultures showed characteristics compatible to those established by the International Society for Cellular Therapy, including proliferation as plastic-adherent cells, immunophenotype (expression of CD105, CD73 and CD90 and low or no expression of CD45, CD14, CD34 and HLA-DR) and the capacity differentiation into mesodermal cell lineages [26]. These results show that the sternum of patients with IHD or VHD can be a source for collecting both BMMC and MSC, and that the type of heart disease does not influence the establishment of cultures. Since it is easier to collect sternal than femoral bone marrow in patients undergoing median sternotomy, this alternative source can be considered in cases of autologous cell therapy.

The proliferative capacity of MSC used in our study was confirmed in the first weeks and was maintained throughout the period of cultivation. Cultures were established from $30 \%$ of the samples, which could be explained by the fact that these are elderly patients, with lower bioavailability of red bone marrow and augmented cellular aging, which causes DNA damage, apoptosis and a reduction of the pool of undifferentiated cells and, consequently, proliferative potential $[27,28]$. However, no association was observed between age and establishment of culture ( $p=0.465)$. On the other hand, the establishment of MSC cultures was positively associated with presence of dyslipidemia in IHD patients and the use of statins. It is known that statins are able to modulate endothelial progenitor cells, another example of adult stem cell, increasing their in vitro proliferative capacity [29]. In contrast, the presence of other factors inherent to heart diseases does not seem to affect the ability of establishment of MSC cultures.

The low frequency of CFU-F $\left(1 / 1 \times 10^{6}\right.$ MSC/BMMC) observed in the present study can also be related to low proliferative potential of cells isolated from the sternal compartment. The initial expansion of cultures is a result of CFU-F present in the sample (single cells that continue to divide to form colonies of cloned cells) [7], so 


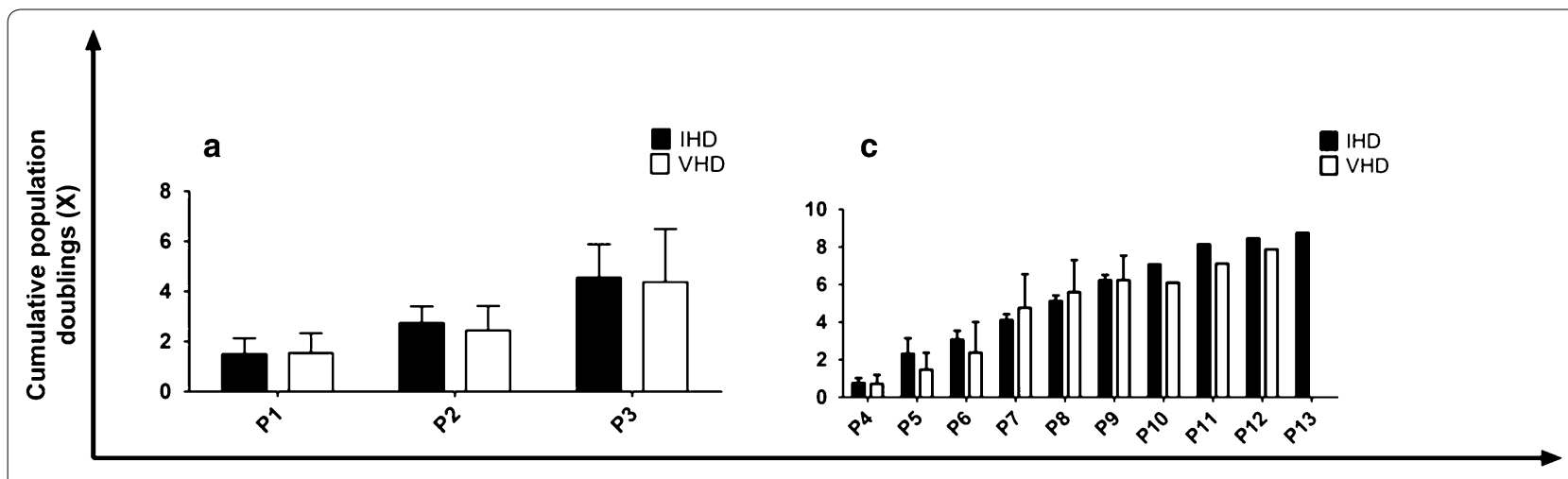

Passage


Passage

Fig. 6 In vitro expansion kinetics of MSC isolated from sternum of ischemic (IHD) and non-ischemic valvular heart disease (VHD). a, c Average cumulative population doubling (CPD) and cumulative days in each passage of IHD and VHD samples. $\mathbf{a}, \mathbf{b}$ From P1 to P3. c, d From P4. Sample size (n) is shown in Fig. 5

that a lower number of colonies suggests a lower success in the establishment of cultures, besides changes in the functional capacity of MSC [18]. Age has been already shown to be closely related to the number of CFU-F, as reported by several studies [16, 18, 30,31]. Baxter et al. [30], for example, reported a great difference in the number of CFU-F in BM samples from healthy donors of old age (59-75 years) and pediatric donors (0-18 years) $\left(3.2 \pm 1.7 / 10^{6}\right.$ vs. $29.0 \pm 4.7 / 10^{6}$ BMMC, respectively). Our study showed that the frequency of CFU-F obtained from the sternal $\mathrm{BM}$ of heart disease patients was approximately two times smaller. These results suggest that not only increasing age, but also the presence of specific factors associated with cardiovascular disease-such as molecules and drugs used that may affect common pathways to the proliferation and homing process-could decrease the regenerative capacity of endogenous BM stem cells [27]. Ito and Suda [32] suggested that metabolic requirements of the BM, which direct adult stem cells to anaerobic glycolysis (keeping the cells undifferentiated) or oxidative metabolism (which activates differentiation), can control the process of exhaustion of the stem cell compartment. Thus, the stem cell compartment is directly affected by to the life history of the cardiac patient, related to maintenance of inflammatory states that disrupt homeostasis and accelerates regenerative processes.

Cultures established from sternal BM of the patients were also analyzed for morphology. During the initial period (P0-P3), the cells presented a fibroblastoid morphology, but in later passages, modifications suggestive of senescence were observed. These changes included loss of fibroblastoid aspect, presence of irregular borders, wide cytoplasm and presence of intracellular debris. These differences were also reported for human MSC cultures isolated from the BM of healthy individuals [31] and for cultures of trabecular osteoblasts [33], suggesting that they are imposed by the two-dimensional in vitro cultivation condition. Cultures older than P3-P4 were more difficult to expand and/or lost the ability to proliferate, which is important since, even aiming at the use of MSC (which are considered the adult stem cells with greater therapeutic potential), clinical protocols for cardiovascular diseases require large cell numbers [34]. This decrease in proliferative potential of MSC was also reported by Choumerianou et al. [31], who observed that MSC isolated from children ( $4 \pm 1$ years old) were more easily expanded until, at least, P6 than cells from healthy 
adults (54 \pm 5 years old), which were more difficult to expand after P4. The authors have also observed a relationship of these findings with shortening of telomeres presented by MSC from adults. Telomeres are known to play an important role in the molecular aging process of cells [35].

Few studies have compared cells isolated from different sites such as sternal and iliac crest. Adams et al. [36] showed that MSCs isolated from equine sternum and ilium had similar characteristics, without difference between growth rates. In sheep, the sternum was considered a good source of bone marrow MSC, with cell division cycle and proliferative potential similar to the cells from iliac bones, showing that a sample from one site is representative of the whole [37]. Human stromal stem cell populations reside in different tissues and the human MSC isolated from iliac crest, sternum and vertebrae bone marrow have also shown similar immunophenotype but different growth and differentiation abilities, suggesting that they may not represent equivalent cell sources for therapeutic applications [38].

The limitations of our study are consistent to those involving collections of biological samples from patients (different sample collectors, different locations of the sternum for bone marrow aspiration, different volumes collected, etc.). Later, the influence of the pathophysiological condition of the patient (presence of disease and associated factors) lead to low proliferative capacity of isolated cells, mainly in a two-dimensional system for in vitro growth, which in our case, represented approximately $30 \%$ of success in establishment. Anyway, in order to assist the medical conduct intending to use protocols based on isolated cells of the bone marrow, our group is also investigating the mechanisms involved with the homing of stem cells, mainly focused on the modulation of the chemokine stromal-derived factor-1 (SDF-1) and its receptor, CXCR4, beyond the inflammatory profile of patients. This data may identify if the cells are capable of being stimulated to cell migration and settlement in cardiac tissue differentially in ischemic and valvular cardiopathies through the expression of these molecules.

\section{Conclusions}

We showed that it is possible to isolate and cultivate MSC from small volumes of sternal bone marrow of cardiac patients. Valvular and ischemic heart diseases, even with variable pathological and physiological aspects, do not have different influences on the proliferative capacity or differentiation potential of the isolated MSC, so that the autologous cell therapy protocols with these cells can be designed for both diseases. However, the processes of expansion and exhaustion of the BM stem cell population are probably influenced/modulated by risk factors such as diabetes, hypertension, smoking, obesity and dyslipidemia, in addition to pharmacological therapy. These factors must be considered, as they may contribute to the failure of the proliferation of MSC cultures, necessary for autologous cell therapy. However, these cells can be safely isolated, and used in in vitro experiments, such as tests for drugs, besides transcriptome and proteome analyses according to the different stages of the disease and patient condition. Additionally, MSC are known for their high potential for regeneration and secretion of paracrine factors [39]. In this context, the discovery of mechanisms that can modulate and increase the therapeutic capacity of the MSC is a constant objective in this area of research, which aims at better therapeutic strategies for the therapy of cardiovascular diseases.

\section{Additional file}

Additional file 1. Flow cytometry analysis of size and granularity (FFS $x$ SSC) and staining of antibody-isotypes controls.

\section{Abbreviations}

BM: bone marrow; BMMC: bone marrow mononuclear cells; CFU-F: colony forming unit-fibroblast; CPD: cumulative population doubling; IHD: ischemic heart disease; MSC: mesenchymal stem cell; PDT: population doubling time; VHD: non-ischemic valvular heart disease.

\section{Authors' contributions}

LDD substantial contributions to conception and design, sample collection, acquisition of data, analysis and interpretation of data; involved in drafting the manuscript and revising it critically for important intellectual content. KRC contributions to statistical analysis, analysis and interpretation of data. CG Sample collection, acquisition of data, interpretation of data and critical evaluation article. MKS sample collection, critical evaluation article. GS sample collection, critical evaluation article. PVBP substantial contributions to analysis and interpretation of flow cytometry. DTC substantial contributions to analysis and interpretation of flow cytometry. RAKK sample collection, interpretation of data and critical evaluation article. BDS contributions to conception and design, acquisition of data, analysis and interpretation of data; involved in drafting the manuscript and revising it critically for important intellectual content. NBN substantial contributions to conception and design, contributions to statistical analysis, data and English review, critical evaluation article MMM substantial contributions to conception and design, analysis and interpretation of data; involved in drafting the manuscript and revising it critically for important intellectual content. All authors read and approved the final manuscript.

\section{Author details}

1 Programa de Pós-graduação em Ciências da Saúde-Cardiologia, Instituto de Cardiologia/Fundação Universitária de Cardiologia, Avenida Princesa Isabel, $\mathrm{n}^{\circ}$ 370, $3^{\circ}$ andar, Porto Alegre, RS CEP: 90620-001, Brazil. ${ }^{2}$ Universidade Federal de São Paulo, São José dos Campos, SP, Brazil. ${ }^{3}$ Serviço de Patologia Clínica, Hospital de Clínicas de Porto Alegre, Porto Alegre, RS, Brazil. ${ }^{4}$ Laboratório de Citometria de Fluxo, Centro Regional de Hemoterapia do Hospital das Clínicas da Faculdade de Medicina de Ribeirão Preto/Universidade de São Paulo, São Paulo, SP, Brazil. ${ }^{5}$ Universidade Federal de Ciências da Saúde de Porto Alegre, Porto Alegre, RS, Brazil. ${ }^{6}$ Faculdade de Medicina, Universidade Federal do Rio Grande do Sul, Porto Alegre, RS, Brazil. ${ }^{7}$ Laboratório de Células-Tronco e Engenharia de Tecidos, Universidade Luterana do Brasil, Canoas, RS, Brazil.

\section{Acknowledgements}

The authors thank the Instituto de Cardiologia surgical department staff by the collection of BM samples used in this study, in particular, Alexsandra 
Balbinot, Daniel Schroeder and Paula Nesralla. We would also like to thank Andréia Escosteguy Vargas by technical and scientific support, and Camila Bonaldo and Daiane dos Santos by collaboration in flow cytometry. This work was supported by Conselho Nacional de Desenvolvimento Científico e Tecnológico (CNPq).

\section{Competing interests}

The authors declare that they have no competing interests.

\section{Consent for publication}

Not applicable.

\section{Ethics approval and consent to participate}

The study was performed conform the declaration of Helsinki and approved by the ethics committee and local authorities (UP 4397/09) and all participants signed the informed consent form prior to their inclusion in the study.

\section{Funding}

This work was supported by CNPq-Conselho Nacional de Desenvolvimento Científico e Tecnológico; CAPES-Coordenação de Aperfeiçoamento de Pessoal de Nível Superior/Programa de Cooperação Acadêmico (Procad); FAPERGSFundação de Amparo à Pesquisa do Estado do Rio Grande do Sul.

\section{Publisher's Note}

Springer Nature remains neutral with regard to jurisdictional claims in published maps and institutional affiliations.

Received: 11 April 2017 Accepted: 11 July 2017

Published online: 25 July 2017

\section{References}

1. Kalil RAK, Ott D, Sant'Anna R, Dias E, Marques-Pereira JP, Delgado-Cãnedo A, Nardi NB, Sant'Anna JRM, Prates PR, Nesralla I. Autologous transplantation of bone marrow mononuclear stem cells by mini-thoracotomy in dilated cardiomyopathy: technique and early results. Sao Paulo Med J. 2008; 126:75-81

2. Sant'Anna RT, Kalil RA, Pretto Neto AS, Júnior FP, Fracasso J, Sant'Anna JR, Marques M, Markoski M, Prates PR, Nardi NB. Global contractility increment in nonischemic dilated cardiomyopathy after free wall-only intramyocardial injection of autologous bone marrow mononuclear cells: an insight over stem cells clinical mechanism of action. Cell Transpl. 2010;19:959-64.

3. Strauer BE, Brehm M, Zeus T, Köstering M, Hernandez A, Sorg RV, Kögler $G$, Wernet P. Repair of infarcted myocardium by autologous intracoronary mononuclear bone marrow cell transplantation in humans. Circulation. 2002;106:1913-8.

4. Abdel-Latif A, Bolli R, Tleyjeh IM, Montori VM, Perin EC, Hornung CA, Zuba-Surma EK, Al-Mallah M, Dawn B. Adult bone marrow-derived cells for cardiac repair: a systematic review and meta-analysis. Arch Intern Med. 2007;167:989-97.

5. Gyöngyösi M, Wojakowski W, Lemarchand P, Lunde K, Tendera M, Bartunek J, Marban E, Assmus B, Henry TD, Traverse JH. Meta-analysis of cell-based CaRdiac stUdiEs (ACCRUE) in patients with acute myocardial infarction based on individual patient data. Circ Res. 2015;116:1346-60.

6. Martin-Rendon E, Brunskill SJ, Hyde CJ, Stanworth SJ, Mathur A, Watt SM. Autologous bone marrow stem cells to treat acute myocardial infarction: a systematic review. Eur Heart J. 2008:29:1807-18.

7. Pittenger MF, Martin BJ. Mesenchymal stem cells and their potential as cardiac therapeutics. Circ Res. 2004;95:9-20.

8. Caplan Al, Dennis JE. Mesenchymal stem cells as trophic mediators. J Cell Biochem. 2006;98:1076-84.

9. Mathiasen AB, Haack-Sørensen M, Kastrup J. Mesenchymal stromal cells for cardiovascular repair: current status and future challenges. Future Cardiol. 2009;5:605-17.

10. Silva GV, Litovsky S, Assad JA, Sousa AL, Martin BJ, Vela D, Coulter SC, Lin J, Ober J, Vaughn WK. Mesenchymal stem cells differentiate into an endothelial phenotype, enhance vascular density, and improve heart function in a canine chronic ischemia model. Circulation. 2005;111:150-6.

11. Lapidot T, Petit I. Current understanding of stem cell mobilization: the roles of chemokines, proteolytic enzymes, adhesion molecules, cytokines, and stromal cells. Exp Hematol. 2002;30:973-81.

12. Pittenger MF, Mackay AM, Beck SC, Jaiswal RK, Douglas R, Mosca JD, Moorman MA, Simonetti DW, Craig S, Marshak DR. Multilineage potential of adult human mesenchymal stem cells. Science. 1999;284:143-7.

13. Williams AR, Trachtenberg B, Velazquez DL, McNiece I, Altman P, Rouy D, Mendizabal AM, Pattany PM, Lopera GA, Fishman J. Intramyocardial stem cell injection in patients with ischemic cardiomyopathy functional recovery and reverse remodeling. Circ Res. 2011;108:792-6.

14. Mathiasen AB, Jørgensen E, Qayyum AA, Haack-Sørensen M, Ekblond A, Kastrup J. Rationale and design of the first randomized, double-blind, placebo-controlled trial of intramyocardial injection of autologous bonemarrow derived mesenchymal stromal cells in chronic ischemic heart failure (MSC-HF Trial). Am Heart J. 2012;164:285-91.

15. Chullikana A, Majumdar AS, Gottipamula S, Krishnamurthy S, Kumar AS, Prakash V, Gupta PK. Randomized, double-blind, phase I/II study of intravenous allogeneic mesenchymal stromal cells in acute myocardial infarction. Cytotherapy. 2014;17:250-61.

16. Fehrer C, Lepperdinger GN. Mesenchymal stem cell aging. Exp Gerontol. 2005;40:926-30.

17. Stenderup K, Justesen J, Clausen C, Kassem M. Aging is associated with decreased maximal life span and accelerated senescence of bone marrow stromal cells. Bone. 2003;33:919-26.

18. Stolzing A, Jones E, McGonagle D, Scutt A. Age-related changes in human bone marrow-derived mesenchymal stem cells: consequences for cell therapies. Mech Ageing Dev. 2008;129:163-73.

19. Suerder D, Manka R, Moccetti T, Cicero VL, Emmert MY, Klersy C, Soncin S, Turchetto L, Radrizzani M, Zuber M. The effect of bone marrow derived mononuclear cell treatment, early or late after acute myocardial infarction: twelve months CMR and long-term clinical results. Circul Res. 2016;119:481-90.

20. Lee JW, Lee SH, Youn YJ, Ahn MS, Kim JY, Yoo BS, Yoon J, Kwon W, Hong IS, Lee $K$. A randomized, open-label, multicenter trial for the safety and efficacy of adult mesenchymal stem cells after acute myocardial infarction. J Korean Med Sci. 2014;29:23-31.

21. SL Chen, WW Fang, Ye F, Liu YH, Qian J, Shan SJ, Zhang JJ, Chunhua $R Z$, Liao LM, Lin S. Effect on left ventricular function of intracoronary transplantation of autologous bone marrow mesenchymal stem cell in patients with acute myocardial infarction. Am J Cardiol. 2004;94:92-5.

22. Bieback K, Hecker A, Kocaömer A, Lannert H, Schallmoser K, Strunk D, Klüer H. Human alternatives to fetal bovine serum for the expansion of mesenchymal stromal cells from bone marrow. Stem Cells. 2009;27:2331-41.

23. Chen FG, Zhang WJ, Bi D, Liu W, Wei X, Chen FF, Zhu L, Cui L, Cao Y. Clonal analysis of nestinâ $\epsilon^{\prime \prime}$ vimentin + multipotent fibroblasts isolated from human dermis. J Cell Sci. 2007;120:2875-83.

24. Kretlow JD, Jin Y-Q, Liu W, Zhang WJ, Hong T-H, Zhou G, Baggett LS, Mikos AG, Cao Y. Donor age and cell passage affects differentiation potential of murine bone marrow-derived stem cells. BMC Cell Biol. 2008;9:60.

25. Meirelles LdS, Nardi NB. Murine marrow derived mesenchymal stem cell: isolation, in vitro expansion, and characterization. Br J Haematol. 2003;123:702-11.

26. Dominici M, Le Blanc K, Mueller I, Slaper-Cortenbach I, Marini F, Krause D, Deans R, Keating A, Prockop D, Horwitz E. Minimal criteria for defining multipotent mesenchymal stromal cells. The International Society for Cellular Therapy position statement. Cytotherapy. 2006;8:315-7.

27. Mendelsohn AR, Larrick JW. Rejuvenation of adult stem cells: is ageassociated dysfunction epigenetic? Rejuvenation Res. 2013;16:152-7.

28. Ogawa T, Kitagawa M, Hirokawa K. Age-related changes of human bone marrow: a histometric estimation of proliferative cells, apoptotic cells, T cells, B cells and macrophages. Mech Ageing Dev. 2000;117:57-68.

29. Wang W, Lang JK, Suzuki G, Canty JM Jr, Cimato T. Statins enhance clonal growth of late outgrowth endothelial progenitors and increase myocardial capillary density in the chronically ischemic heart. PLOS ONE. 2011;6:e24868. 
30. Baxter MA, Wynn RF, Jowitt SN, Wraith J, Fairbairn L, Bellantuono I. Study of telomere length reveals rapid aging of human marrow stromal cells following in vitro expansion. Stem Cells. 2004;22:675-82.

31. Choumerianou DM, Martimianaki G, Stiakaki E, Kalmanti L, Kalmanti M, Dimitriou H. Comparative study of stemness characteristics of mesenchymal cells from bone marrow of children and adults. Cytotherapy. 2010;12:881-7.

32. Ito K, Suda T. Metabolic requirements for the maintenance of self-renewing stem cells. Nat Rev Mol Cell Biol. 2014;15:243-56.

33. Kassem M, Ankersen L, Eriksen EF, Clark B, Rattan S. Demonstration of cellular aging and senescence in serially passaged long-term cultures of human trabecular osteoblasts. Osteoporos Int. 1997;7:514-24.

34. Hare JM, Fishman JE, Gerstenblith G, Velazquez DLD, Zambrano JP, Suncion VY, Tracy M, Ghersin E, Johnston PV, Brinker JA. Comparison of allogeneic vs autologous bone marrow-derived mesenchymal stem cells delivered by transendocardial injection in patients with ischemic cardiomyopathy: the POSEIDON randomized trial. JAMA. 2012;308:2369-79.
35. Blackburn EH. Switching and signaling at the telomere. Cell. 2001;106:661-73.

36. Adams M, Goodrich L, Rao S, Olea-Popelka F, Phillips N, Kisiday J, Mcllwraith C. Equine bone marrow-derived mesenchymal stromal cells (BMDMSCs) from the ilium and sternum: Are there differences? Equine Vet J. 2013;45:372-5.

37. Harker G, Zbroja R, Wass J, Vincent P, Stephens F. Cell cycle homogeneity in bone marrow samples from different sites: flow cytometric evaluation of multiple samples from sheep. Exp Hematol. 1983;11:1037-41.

38. Picchi J, Trombi L, Spugnesi L, Barachini S, Maroni G, Brodano GB, Boriani S, Valtieri M, Petrini M, Magli MC. HOX and TALE signatures specify human stromal stem cell populations from different sources. J Cell Physiol. 2013;228:879-89.

39. Markoski MM. Advances in the use of stem cells in veterinary medicine: from basic research to clinical practice. Scientifica. 2016;2016:4516920.

\section{Submit your next manuscript to BioMed Central and we will help you at every step:}

- We accept pre-submission inquiries

- Our selector tool helps you to find the most relevant journal

- We provide round the clock customer support

- Convenient online submission

- Thorough peer review

- Inclusion in PubMed and all major indexing services

- Maximum visibility for your research

Submit your manuscript at www.biomedcentral.com/submit 